\title{
Pemilihan Alternatif Terbaik Cleaner Production Pada Industri Keripik Singkong Dalam Mendukung Sustainable Manufacturing
}

\author{
Millatul Ulya ${ }^{1}$, Khoirul Hidayat ${ }^{2}$ \\ 1,2Prodi Teknologi Industri Pertanian, Universitas Trunojoyo Madura \\ 1millatul.utm@gmail.com
}

\begin{abstract}
ABSTRAK
Produksi bersih merupakan salah satu strategi dalam sustainable manufacturing yang dapat digunakan untuk meningkatkan kinerja lingkungan di industri pengolahan keripik singkong. Tahap awal dalam penilaian produksi bersih adalah identifikasi peluang produksi bersih dengan metode analisis deskriptif dan analisis keseimbangan material dan energi. Berdasarkan analisis neraca keseimbangan material dan energi, jumlah bahan baku 3,6 ton singkong menghasilkan non product output air sisa pencucian, 1,5 liter minyak jelantah dan $900 \mathrm{~kg}$ kulit singkong. Berdasarkan analisis neraca kesetimbangan massa dan energi tersebut, terdapat 5 peluang produksi bersih yaitu penghematan air, produksi sabun dari minyak jelantah, pengolahan kulit singkong menjadi tepung kulit singkong, kerupuk kulit singkong dan gula cair. Perlu dilakukan penelitian lanjut berupa sintesis untuk menentukan alternatif terbaik dari beberapa peluang produksi bersih yang telah teridentifikasi.
\end{abstract}

Kata Kunci: Produksi bersih, keripik singkong.

\section{Identification of Cleaner Production Opportunity in Cassava Chips Industry in Supporting Sustainable Manufacturing}

\begin{abstract}
Cleaner production is one strategy in sustainable manufacturing that can be used to improve environmental performance in cassava chips processing industry. The initial stage in the assessment of cleaner production is the identification of cleaner production opportunities by descriptive analysis methods and the analysis of material and energy balance. Based on the analysis of material and energy balance, the amount of raw material is 3.6 tons of cassava yielded non product output of wash water remaining, 1.5 liter of used cooking oil and $950 \mathrm{~kg}$ of cassava peel. Based on the analysis of material and energy balance, there are 5 cleaner production opportunity that is water saving, soap production from used cooking oil, processing of cassava peel to cassava peel flour, cassava peel cracker and liquid sugar. Further research should be done in the form of synthesis to determine the best alternative of several cleaner production opportunities that have been identified.
\end{abstract}

Keywords: Cleaner production, cassava chips, metode Bayes. 


\section{PENDAHULUAN}

Salah satu makanan khas madura adalah keripik singkong, yang produsennya merupakan industri kecil menengah. Di Kabupaten Sumenep, sentra industri singkong terletak di Kecamatan Manding. Jumlah industri kecil dan menengah untuk jenis keripik dan kerupuk pada tahun 2015 sebanyak 50 industri (Disperindag Sumenep, 2015), sehingga Kabupaten Sumenep berpotensi menghasilkan banyak limbah dari hasil proses produksi industri-industri tersebut. Pengelolaan lingkungan yang baik untuk menangani masalah pencemaran akibat limbah industri keripik juga harus diperhatikan, agar kinerja lingkungan dari industri keripik meningkat. Dengan kinerja lingkungan yang baik, maka sustainability dalam industri keripik singkong dapat terjaga dengan baik. Salah satu industri kecil menengah pengolahan keripik singkong adalah UD. Dua Saudara "Bintang 9" yang terletak di Desa Giring Timur Kecamatan Manding Kabupaten Sumenep. Bahan baku yang digunakan adalah singkong atau keripik singkong yang mentah. Pada proses produksi keripik singkong, menghasilkan limbah berupa air sisa pencucian bahan baku, minyak goreng jelantah, dan kulit singkong. Selama ini UD. Dua Saudara melakukan pengelolaan limbah cair berupa air sisa pencucian dengan mengalirkan pada saluran pembuangan, minyak jelantah sebesar $\pm 1,5$ liter dengan penanganan juga dibuang pada saluran pembuangan, penanganan limbah padat kulit bawang yaitu dengan dibakar, sedangkan untuk limbah padat kulit singkong yang merupakan limbah paling dominan dihasilkan belum dilakukan pengelolaan secara optimal. Limbah kulit singkong hanya dijual kepada warga untuk dijadikan pakan ternak dengan harga Rp. 1.000 per $\mathrm{kg}$ dan sisanya ditumpuk hingga membusuk yang kemudian dibakar.

Tanpa disadari sebenarnya limbah merupakan peluang dalam menambah nilai ekonomi. Salah satu upaya menambah nilai ekonomi bagi pihak industri yaitu dengan menerapkan produksi bersih (Indrasti dan Fauzi, 2009). Produksi bersih adalah salah satu strategi dalam sustainable manufacturing. Produksi bersih merupakan strategi pengelolaan lingkungan yang prefentif, diterapkan terus-menerus pada proses produksi dan seluruh daur hidup produk dengan tujuan mengurangi resiko terhadap manusia dan lingkungan (UNEP, 2003). Tujuan penerapan produksi bersih suatu industri adalah untuk meningkatkan keuntungan dan efisiensi dengan memperhatikan kestabilan lingkungan selama daur hidup produk dengan beberapa alternatif pilihan yang diterapkan. Sistem produksi bersih berjalan dengan baik ditandai dengan berkurangnya bahan baku, air dan energi yang digunakan, terdapat penanganan limbah industri serta minimum jumlah limbah padat dan limbah cair (Purwanto, 2005).

Industri kecil dan menengah seperti UD. Dua Saudara Manding Kabupaten Sumenep perlu dikaji dalam hal penerapan produksi bersih, agar dampak negatif dari keberadaan industri ini bisa diminimalisir dan diharapkan dapat menambah keuntungan terhadap beberapa pihak. Umumnya industri kecil dan menengah masihkurang efisien dalam menggunakan sumber daya alam, serta teknologi proses sederhana yang kadang kurang efisien dan kurang bersih sehingga masih berpotensi menghasilkan 
limbah dan mencemari lingkungan sekitar (Widodo, 2017).

Tahapan penerapan produksi bersih menurut Purwanto (2005) ada 5, yaitu: perencanaan dan organisasi, kajian dan identifikasi peluang produksi bersih, Analisis kelayakan, implementasi produksi bersih serta monitoring dan evaluasi. Tahap identifikasi peluang produksi bersih telah dilakukan oleh Ulya dan Hidayat (2017), terdapat 5 peluang produksi bersih pada industri keripik singkong, yaitu penghematan air, produksi sabun dari minyak jelantah, pengolahan kulit singkong menjadi tepung kulit singkong, kerupuk kulit singkong dan gula cair. Dari 5 peluang atau alternatif produksi bersih tersebut, perlu dikaji tentang pemilihan alternatif terbaik yang akan diprioritaskan untuk diimplementasikan lebih dulu pada UD. Dua Saudara.

Pemilihan alternatif terbaik dapat dilakukan menggunakan pendekatan pengambilan keputusan berbasis multikriteria. Pengambilan keputusan dengan banyak alternatif dan kriteria majemuk dapat dipengaruhi oleh beberapa aspek yang dapat mempengaruhi kecepatan dan keakuratan hasil yang diperoleh (Rangkuti, 2011). Salah satu metode yang dapat digunakan adalah metode Bayes, yang merupakan metode untuk menghasilkan keputusan yang optimal dengan mempertimbangkan berbagai kriteria.

Penelitian ini bertujuan untuk mengidentifikasi kriteria dalam penentuan alternatif produksi bersih dan menentukan alternatif terbaik peluang produksi bersih di industri keripik singkong menggunakan metode Bayes. Hasil penelitian ini dapat menjadi rekomendasi bagi industri UD. Dua Saudara untuk meningkatkan efisiensi produksi, menurunkan tingkat pencemaran, dan meningkatkan nilai ekonomi.

\section{METODE PENELITIAN}

Penelitian ini dilaksanakan pada industri keripik singkong UD. Dua Saudara, Kecamatan Manding Kabupaten Sumenep Madura. Tahapan penelitian ini sebagai berikut:

\section{Identifikasi Alternatif peluang produksi bersih}

Tahap ini dilakukan melalui kajian penelitian pendahuluan yang telah dilakukan oleh Ulya dan Hidayat (2018), yang menghasilkan 5 alternatif yaitu: penghematan air, produksi sabun dari minyak jelantah, pengolahan kulit singkong menjadi tepung kulit singkong, kerupuk kulit singkong dan gula cair.

\section{Identifikasi kriteria pengam- bilan keputusan}

Tahap ini dilakukan melalui studi literatur dari jurnal penelitian terdahulu, dan dikonfirmasi melalui wawancara terhadap pakar dan pemilik industri keripik singkong untuk menyesuaikan dengan kemampuan industri terkait.

\section{Penentuan alternatif terbaik}

Penetapan alternatif terbaik dilakukan dengan menyebar kuesioner kepada pakar yaitu pemilik UD Dua Saudara, pemilik UD Muris Saronggi, dan pemilik UKM Baby Pamlolokan dengan mempertimbangkan pada beberapa kriteria. Hasil dari kuesioner selanjutnya dianalisis menggunakan metode bayes. Menurut Rangkuti (2011), pembuatan keputusan menggunakan metode bayes dapat dinyatakan dengan suatu bilangan antara 0 dan 1, dan penentuan bobot bayes berdasarkan pada tingkat keyakinan, kepercayaan, pengalaman dan latar belakang pengambil keputusan atau penulis. Metode penilaian yang digunakan 
adalah skala ordinal yaitu skala 1 untuk penilaian sangat kurang sampai pada skala 5 untuk penilaian sangat bagus. Adapun persamaan metode bayes untuk menghitung nilai setiap alternatif dapat disampaikan dengan rumus sebagai berikut:

Total Nilai $\mathrm{i}=$

$\sum_{j=1}^{m}$ Nilai ij (Kriteria $j$ )

Keterangan :

Total nilai $\mathrm{i}=$ total nilai akhir dari alternatif ke-i;

Nilai ij = nilai dari alternatif ke-i pada kriteria ke-j;

Krit $\mathrm{j}=$ tingkat kepentingan (bobot) kriteria ke-j;

$\mathrm{i}=1,2,3, . . \mathrm{n} ; \mathrm{n}=$ jumlah alternatif

$\mathrm{j}=1,2,3, . . \mathrm{m} ; \mathrm{m}=$ jumlah kriteria

Jayanti (2012) mengatakan bahwa, untuk mencari nilai dari bobot per ktiteria, bobot total, dan nilai probabilitas per kriteria dapat dilakukan perhitungan sebagai berikut:

a. Bobot Per Kriteria, dapat dihitung dengan menjumlahkan nilai dari option pada masing-masing pertanyaan untuk setiap kriteria.

b. Bobot Total, diperoleh dengan menjumlahkan semua dari nilai bobot masing-masing kriteria.

c. Probabilitas Per Kriteria, diperoleh dengan menghitung bobot per kriteria dibagi dengan bobot total.

d. Total Probabilitas, diperoleh dengan menjumlahkan

keseluruhan nilai probabilitas dari masing-masing kriteria dengan total harus 1 .

Tabel hasil dari pembobotan alternatif terhadap beberapa kriteria dengan menggunakan metode bayes dapat dilihat pada Tabel 1.

Data yang telah diperoleh baik data kuantitatif dan kualitatif, selanjutnya diolah menggunakan Microsoft Office Exel 2010, kemudian disajikan dalam bentuk tabulasi data yang bertujuan untuk mengklasifikasikan serta memudahkan dalam menganalisis data.

\section{HASIL DAN PEMBAHASAN \\ Penentuan Kriteria pengambilan keputusan}

Pengambilan keputusan untuk memilih alternatif terbaik penerapan produksi bersih dilakukan dengan menggunakan tiga aspek kriteria, yang dijabarkan menjadi beberapa sub kriteria. Aspek yang dilakukan sebanyak 3 yaitu:

\section{Aspek lingkungan}

Aspek lingkungan berkaitan erat tentang limbah atau buangan yang dihasilkan oleh industri baik berupa padat, cair, atau gas. Jadi alternatif produksi bersih harus dapat menimimalkan limbah hasil produksi dan memperhatikan limbah apa saja yang akan dihasilkan beserta penanganannya.

Tabel 1. Tabel Hasil Pembobotan Alternatif

\begin{tabular}{|c|c|c|c|c|c|}
\hline \multirow{2}{*}{ Alternatif } & \multicolumn{3}{|c|}{ Kriteria } & \multirow{2}{*}{ Nilai Alternatif } & \multirow{2}{*}{ Peringkat } \\
\hline & A & $\mathrm{B}$ & $\mathrm{C}$ & & \\
\hline 1 & $\mathrm{~A} 1$ & B1 & C1 & $\left(A 1{ }^{*} X\right)+(B 1 Y)+(C 1 * Z)$ & Alternatif peringkat 1 \\
\hline 2 & $\mathrm{~A} 2$ & $\mathrm{~B} 2$ & $\mathrm{C} 2$ & $\left(\mathrm{~A} 2^{*} \mathrm{X}\right)+(\mathrm{B} 2 \mathrm{Y})+\left(\mathrm{C} 2^{*} \mathrm{Z}\right)$ & adalah yang terbesar \\
\hline 3 & A3 & B3 & $\mathrm{C3}$ & $\left(A 3^{*} X\right)+(B 3 Y)+\left(C 3^{*} Z\right)$ & nilainya, dst \\
\hline Bobot bayes & $\mathrm{X}$ & $\mathrm{Y}$ & Z & & \\
\hline
\end{tabular}


Tabel 2. Hasil Perolehan Bobot Kriteria (Bobot Bayes) oleh Pakar

\begin{tabular}{|c|c|c|c|c|c|}
\hline \multirow{2}{*}{ Kriteria } & \multicolumn{3}{|c|}{ Bobot kriteria } & \multirow{2}{*}{ Total } & \multirow{2}{*}{ Bobot Bayes } \\
\hline & $\mathrm{R} 1$ & $\mathrm{R} 2$ & R3 & & \\
\hline Aspek Ekonomi & 4 & 3 & 3 & 10 & $10 / 29=0,35$ \\
\hline Aspek Teknis & 3 & 3 & 3 & 9 & $9 / 29=0,3$ \\
\hline Aspek Lingkungan & 4 & 3 & 3 & 10 & $10 / 29=0,35$ \\
\hline Total & & & & 29 & 1 \\
\hline
\end{tabular}

\section{Aspek ekonomi}

Aspek ekonomi adalah aspek tentang kemurahan biaya dan keuntungan yang diperoleh dalam menjalankan suatu usaha. Alternatif yang terpilih hendaknya memiliki biaya produksi yang rendah dan menghasilkan profit bagi industri.

\section{Aspek teknis}

Beberapa hal yang termasuk dalam aspek teknis antara lain: kemudahan proses produksi, kemudahan operasional alat dan mesin produksi, proses produksi tidak terlalu lama dan rendemen yang diperoleh tinggi. Aspek teknis ini perlu dikonfrmasi lebih lanjut pada pemilik industri karena berkaitan erat dengan kemampuan industri dalam implementasi produksi bersih.

Pemilihan Tiga aspek berdasarkan hasil studi pustaka dan wawancara pada pakar, yaitu 3 pemilik industri keripik singkong. Sub kriteria dari ketiga aspek tersebut yaitu meliputi aspek ekonomi tentang biaya produksi rendah dan hasil menguntungkan, aspek teknis tentang proses produksi mudah, kemudahan operasional alat dan ketersediaan alat, serta aspek lingkungan tentang meminimalkan limbah hasil produksi (limbah cair \& padat).

\section{Penentuan Alternatif Terbaik Produksi Bersih di Industri Keripik Singkong

Hasil Penetapan Bobot Kriteria /
Bobot Bayes dan Alternatif
Produksi Bersih

\section{Analisis Bobot Bayes}

Menurut Rangkuti (2011), penentuan bobot bayes berdasarkan pada tingkat keyakinan, kepercayaan, pengalaman dan latar belakang pengambil keputusan, dengan kata lain bersifat subjektif sesuai keinginan pihak pengambil keputusan. Pada penerapan produksi bersih ini digunakan analisis bobot kriteria/ bobot bayes dengan melakukan pembobotan terhadap setiap kriteria yang diujikan terhadap pakar sebagai dasar pertimbangan penentuan bobot bayes yang kemudian diolah menggunakan software Microsoft Office Exel 2010. Bobot kriteria oleh pakar dapat dilihat pada Tabel 2.

Berdasarkan Tabel 2 di atas, diketahui bobot bayes untuk setiap kriteria secara berturut-turut yaitu aspek ekonomi, teknis dan lingkungan memiliki nilai bobot sama tertinggi yaitu 0,35 , dan kemudahan terhadap proses produksi memiliki nilai bobot 0,3 .

Kriteria aspek lingkungan dan aspek ekonomi menjadi prioritas pertama pada penerapan produksi bersih di UD. Dua Saudara Manding. 
Tabel 3. Hasil Bobot Masing-masing Alternatif terhadap beberapa Kriteria

\begin{tabular}{lccc}
\hline \multicolumn{1}{c}{ Alternatif } & \multicolumn{3}{c}{ Kriteria } \\
\cline { 2 - 4 } & $\begin{array}{c}\text { Aspek } \\
\text { Ekonomi }\end{array}$ & Aspek Teknis & $\begin{array}{c}\text { Aspek } \\
\text { Lingkungan }\end{array}$ \\
\hline Penghematan air & 2,3 & 2 & 3 \\
Kerupuk kulit singkong & 3,6 & 3,3 & 3,3 \\
Gula cair kulit singkong & 2,3 & 2 & 2,6 \\
Tepung kulit singkong & 4 & 4 & 3 \\
$\begin{array}{l}\text { Sabun dari minyak } \\
\text { jelantah }\end{array}$ & 2 & 2 & 2 \\
\hline
\end{tabular}

Kriteria tersebut diharapkan dapat berpengaruh terhadap berkurangnya timbulan limbah hasil samping produksi baik limbah padat dan limbah cair disekitar industri tersebut tanpa mengabaikan biaya produksi yang akan menjadi beban industri.

\section{Hasil Pembobotan Alternatif Penerapan Produksi Bersih}

Hasil pembobotan masingmasing alternatif terhadap beberapa kriteria yang diperoleh dari penyebaran kuesioner terhadap pakar dapat dilihat pada Tabel 3 berikut:

Dari hasil rekap bobot masing-masing alternatif terhadap beberapa kriteria diatas, penjelasan dan penjabaran mengenai masingmasing alternatif adalah sebagai berikut:

1. Penghematan air, dari aspek lingkungan memiliki skor yang lebih tinggi dibanding secara teknis dan ekonomi. Karena untuk mengimplementasikan alternatif ini, industri perlu investasi peralatan (pipa, tandon, dsb) yang akan memberatkan industri baik secara teknis maupun ekonomi.

2. Kerupuk kulit singkong

Kerupuk kulit singkong dinilai lebih tinggi pada aspek ekonomi, karena memang dapat dijual ke konsumen, sehingga diharapkan dapat menambah profit industri. Secara teknis dan lingkungan juga cukup baik, karena pembuatan dan alat yang digunakan sangat sederhana, dan limbah yang dihasilkan juga minimum dan tidak membahayakan lingkungan.

3. Gula cair kulit singkong

Alternatif ini dinilai susah diimplementasikan baik secara teknis, ekonomi maupun lingkungan, karena proses pembuatannya membutuhkan waktu yang lama, butuh bahan kimia juga yang bisa menambah limbah industri serta biaya produksi yang tidak murah dan produk belum tentu dapat bersaing di pasar, karena harganya pasti lebih mahal daripada gula yang lain.

4. Tepung kulit singkong

Produk ini merupakan produk antara, masih harus diolah lebih lanjut oleh konsumen. Pembuatan tepung kulit singkong sangat sederhana dan tidak meninggalkan limbah yang banyak, oleh karena itu para pakar menilaialternatif ini sangat 
Tabel 4. Hasil Perhitungan Penetapan Alternatif Terbaik Penerapan Produksi Bersih UD Dua Saudara Manding Menggunakan Metode Bayes

\begin{tabular}{lcccc}
\hline \multicolumn{1}{c}{ Alternatif } & \multicolumn{3}{c}{ Kriteria } & \multicolumn{2}{c}{$\begin{array}{c}\text { Nilai } \\
\text { Keputusan }\end{array}$} \\
\cline { 2 - 5 } & $\begin{array}{c}\text { Aspek } \\
\text { ekonomi }\end{array}$ & Aspek teknis & $\begin{array}{c}\text { Aspek } \\
\text { lingkungan }\end{array}$ \\
\hline $\begin{array}{l}\text { Penghematan air } \\
\begin{array}{l}\text { Tepung kulit } \\
\text { singkong }\end{array}\end{array}$ & 2,3 & 2 & 3 & 2,46 \\
Kerupuk Kulit Singkong & 3,6 & $\mathbf{3 , 3}$ & $\mathbf{4}$ & $\mathbf{3 , 6 8 3}$ \\
$\begin{array}{l}\text { Gula Cair Kulit } \\
\text { Singkong }\end{array}$ & 2,3 & 3,3 & 3,3 & 3,45 \\
$\begin{array}{l}\text { Keripik Kulit Singkong } \\
\text { Sabun dari jelantah }\end{array}$ & 4 & 2 & 2,6 & 2,35 \\
& 2 & 4 & 3 & 3,65 \\
\hline Bobot Bayes & $\mathbf{0 , 3 5}$ & $\mathbf{0 , 3}$ & $\mathbf{0 , 3 5}$ & 2 \\
\hline
\end{tabular}

baik dari segi teknis, ekonomi dan lingkungan.

5. Sabun dari minyak jelantah Pembuatan sabun dari minyak jelantah dinilai susah dari segi teknis, ekonomi dan lingkungan karena menggunakan bahan kimia sehingga dapat menghasilkan limbah lebih banyak ke lingkungan, prosesnya juga lama sehingga produk yang dihasilkan akan memiliki harga pokok produksi yang tinggi sehingga tidak dapat bersaing dengan produk sejenis.

\section{Pemilihan Alternatif Terbaik Penerapan Produksi Bersih \\ Penetapan alternatif terbaik} pada penerapan produksi di UD Dua Saudara Manding-Sumenep dilakukan dengan menggunakan metode Bayes. Hasil penetapan masing-masing alternatif penerapan produksi bersih terhadap beberapa kriteria menggunakan metode Bayes dapat dilihat pada Tabel 4:
Dilihat dari hasil perhitungan menggunakan metode bayes, dapat diketahui bahwa peringkat alternatif tertinggi didapatkan oleh tepung kulit singkong dengan nilai sebesar 3,683. Peringkat alternatif kedua didapatkan oleh keripik kulit singkong dengan nilai sebesar 3,65. Peringkat alternatif ketiga didapatkan oleh kerupuk kulit singkong dengan nilai sebesar 3,45. Sedangkan peringkat alternatif keempat didapatkan oleh gula cair kulit singkong dengan nilai sebesar 2,35 dan peringkat kelima adalah pengolahan minyak jelantah menjadi sabun. Dari keempat alternatif diketahui bahwa tepung kulit singkong mempunyai nilai alternatif tertinggi sehingga dengan demikian pengolahan limbah padat kulit singkong menjadi tepung merupakan alternatif terbaik yang terpilih dan memiliki peluang untuk dikembangkan lebih lanjut. Namun sebelum melakukan impelementasi dari alternatif terbaik tersebut, masih diperlukan analisis kelayakan 
finansial apakah alternatif tersebut layak untuk dijalankan atau tidak secara finansial.

\section{SIMPULAN DAN REKOMENDASI}

Kriteria pengambilan keputusan tentang alternatif produksi bersih ada tida yaitu aspek lingkungan, ekonomi, dan teknis.

\section{DAFTAR PUSTAKA}

Dinas Perindustrian dan Perdagangan Kabupaten Sumenep. 2016. Direktori Industri Kecil Menengah Tahun 2015. Sumenep.

Indrastuti, N dan Fauzi, A.M., 2009. Produksi Bersih. IPB Press. Bogor.

Jayanti, Ni Ketut Dewi Ari. 2012. Implementasi Metode Bayes pada Penilaian Kinerja Dosen. Eksplora Informatika. Denpasar: STMIK STIKOM Bali.

Purwanto, 2005. Penerapan Produksi Bersih untuk Mengembangkan Kawasan Industri Berwawasan Lingkungan. Jurnal IImu Lingkungan, Vol. 3 No. 2. Undip. Semarang.
Hasil alternatif terbaik produksi bersih di industri singkong adalah pengolahan kulit singkong menjadi tepung kulit singkong. Hasil penelitian ini masih harus dianalisis kelayakan finansialnya agar diketahui apakah produksi tepung kulit singkong layak untuk diimplementasikan atau tidak.

Rangkuti, A, Haris. 2011. Teknik Pengambilan Keputusan Multi Kriteria Menggunakan Metode Bayes, MPE, CPI dan AHP. Comtech Vol. 2 No. 1, hal 229238.

Ulya, $M$ dan Hidayat, K. 2018. Identifikasi Peluang Produksi Bersih pada Industri Keripik Singkong. Reka Pangan Vol. 12 No. 1. Hal 78-82.

United Nation Environment Programme (UNEP), 2003. Cleaner Production Assessment in Industries. http://www.uneptie.ora/pc/cp/ diakses tanggal 15 Juli 2017.

Widodo, Lestario, 2017. Potensi Penerapan Produksi Bersih pada Industri Keramik di Probolinggo. Jurnal Teknologi Lingkungan Vol 18 No. 2, hal 192-199. 